О.П.Дзьобань, доктор філософських наук, професор

\title{
СУСПІЛЬНИЙ ІДЕАЛ: ДЕЯКІ ОСОБЛИВОСТІ АНТИЧНОГО РОЗУМІННЯ
}

Для сучасного етапу пошуків оптимальних форм суспільного буття важливим моментом $\epsilon$ усвідомлення процесу становлення уявлень про ідеальний суспільний устрій в історії філософської думки.

Ідеал досконалого суспільства передбачає спосіб реалізації ідеального суспільства в цілому, спробу уявити такий устрій, в якому соціально-економічні, політичні та інші структури є досконалими не тільки самі по собі, а й у цілому. Тобто ідеал досконалого суспільства - це образ такого суспільного ладу, в якому досконалими $\epsilon$ всі його складові.

Дослідження історично першого типу суспільного ідеалу і соціальних і гносеологічних умов виникнення моральних настанов означає і пошук відповідей на питання: коли і чому стає можливим і необхідним поява соціальних ідеалів?

Результати аналізу наукових джерел свідчать, що проблема становлення суспільного ідеалу не має однозначного, загальноприйнятого вирішення. Г.Гусєв зазначає, що «ідеали, мабуть, виникли лише на світанку рабовласницького суспільства, з відділенням розумової праці від фізичної, оскільки вони передбачають вже винятково високий ступінь абстракції у формуванні вищих домінуючих цілей усього життя людини, класу, суспільства» $[1,15]$.

Водночас переважна більшість дослідників $[2 ; 3 ; 4]$ схиляється до думки, що ідеал виникає у тому випадку, якщо людина не задоволена існуючим суспільним життям, усвідомлює свою незадоволеність. Інтереси та цілі роду були інтересами і цілями кожного його члена, a, отже, й не виникало питання про суспільство, яке б найкращим чином сприяло задоволенню потреб особистості. Необхідність у цьому виникає тільки тоді, коли розкладаються родові відносини i вже не можуть забезпечити всім членам громади рівні можливості для відносного благополуччя, коли нерівність стає очевидною. 
Думка про можливість існування суспільного устрою, відмінного від даного, може скластися лише на такому етапі історичного розвитку, коли сама суспільна практика сформувала вже кілька форм суспільної організації, які можуть бути протиставлені одна одній. Тому стає очевидним, що первісне суспільство було не в змозі висунути будь-які ідеали.

Таким чином, поява ідеалів стає можливою не раніше, ніж у рабовласницькому суспільстві, яке зароджується. Принаймні, до цього періоду належить виникнення першого з відомих науці ідеалів суспільного устрою - античного ідеалу «золотого століття». Тому метою даної статті є розгляд деяких характерних особливостей античного розуміння суспільного ідеалу.

Античній людині вся природа, весь космос уявлявся як єдине ціле, як щось живе, одухотворене (космоцентризм). Сама ж людина була лише річчю, знаряддям (цей погляд виникає як наслідок рабства, яке зароджувалося). Рабовласницьке суспільство, що зароджується, ще не знає особистості в різноманітних, індивідуальних проявах засвоєної нею духовної культури. Тут ще немає особистості в соціальному й історичному розумінні. Антична людина - це особистість «природна», тобто живе людське тіло. «Отже, тут тілесножиттєва стихія обгрунтовує себе саму. Вона сама для себе і мета, i засіб. Вона сама для себе і ідеал, і дійсність. Вона вся наскрізь «ідеальна» і наскрізь «реальна» $[5,60]$.

Реальна потреба у виникненні ідеалу суспільного устрою виникає в міру поглиблення майнової нерівності, посилення експлуатації. Так починається ідеалізація родового ладу, первіснообщинних відносин. Основні риси «золотого віку» визначаються інтересами грецьких хліборобів, ідеалізованими в ньому первіснообщинними відносинами.

Ідеал «золотого віку» - це образ цілісного, гармонійного буття, яке сучасники Гесіода вже втратили і яке уявляється сукупністю найзагальніших і тому гранично стійких рис. Очевидно, що саме ці властивості античного ідеалу багато в чому визначили його вплив на формування наступних ідеалів, соціально-політичних теорій. Звичайно, найбільшу роль ідеал «золотого віку» відіграв у створенні інших, більш пізніх ідеалів античного суспільства.

Суспільна думка Стародавньої Греції, що досягла до того часу свого розквіту, не містила ізольованих, не пов'язаних один з одним ідеологічних утворень, породжених різними соціальними групами. 
Вона, скоріше, була єдиним цілим, в якому різні уявлення про досконалу державу, тотожну в античній свідомості суспільству, перепліталися між собою, взаємно впливали один на одного. У рабовласницькому суспільстві проблема належного державного устрою вперше гостро була поставлена софістами, раціоналізм і утилітаризм яких привів до поширення товарних відносин навіть на сферу освіти.

Засновник цієї школи - Протагор, - висуваючи своє знамените положення «людина є міра всіх речей», запропонував не тільки основний принцип теорії пізнання, а й фундаментальний критерій ціннісного ставлення до всіх суспільних явищ. До того мірою всього соціального була держава і іï закони, а єдність індивіда й держави будувалася на підпорядкуванні інтересів самого життя індивіда полісу. Тепер же виникло принципово нове вирішення проблеми взаємовідносин особистості й суспільства - їх примітивна взаємодія, заснована на підпорядкуванні людини суспільству, виявилась розірваною, щоправда, поки що тільки теоретично.

Одні (Гіппій, Антифонт, Каллікл та ін.) вважали, що цивілізація $є$ насильством над людиною, що приписи законів є довільними (штучними), веління ж природи є необхідними [6]. Ці погляди безпосередньо опираються на традицію ідеалу «золотого віку», тому зміни в суспільному житті тлумачаться як процес поступової деградації суспільства. Послідовно реалізуючи свої вихідні посилання, ця група софістів доходить вкрай індивідуалістичних висновків. Якщо держава суперечить природі, якщо закони створені для користі небагатьох, значить «право - сила», сильніший повинен правити, а слабкий підкорятися. Цей логічно виведений крайній індивідуалізм не мав під собою будь-якої реальної соціальної бази і був відкинутий навіть багатьма софістами.

Така сама доля спіткала і інший, «передчасний», висновок софістів - думку про первинну рівність усіх людей, засновану на їх природній основі й спорідненості.

Таким чином, виникнувши як логічний висновок з ідеалу «золотого віку», ідея загальної рівності стає елементом свідомості певної соціальної групи, впливає на ії діяльність. Вкрай індивідуалістичні ідеї софістів були малопривабливими для більшості мислителів усіх часів, проте, поширюючись в Афінах, вони підривали полісну ідеологію і, безсумнівно, сприяли активізації прогресивної приватнопідприємницької діяльності.

Інша група софістів (Протагор, Лікофонт, Фразімах та ін.) у своїх 
поглядах виявилася більш раціоналістичною. Із загальної тези про відносність законів, вони зробили позитивний висновок: потрібно встановлювати закони, корисні людям, які відповідали б взаємній справедливості й чеснотам [5; 6]. Ця ідея вилилася у прообраз теоpiї «суспільного договору», в якому держава уявляється зборами рівноправних громадян, які взаємно забезпечують свою безпеку й обмежують природну свободу.

Сократ вже розуміє, що людина не може жити поза суспільством. Як зазначає Е.Фролов, для Сократа абсолютно безсумнівним був тісний зв'язок між моральною досконалістю і щастям, а щастя людини, що досягається на шляху доброчесності, немислиме без благополуччя суспільства [7]. Але і людина, «мудрець», гідний такого суспільства, в якому панують справедливі за своєю природою закони.

3 цього фундаментального положення Сократ робить висновок: розумною державою повинні керувати мудреці. Таким чином, на місце родової аристократії висувається аристократія духу. Попередньо зазначимо, що ідея держави, керованої мудрецями, стане одним з наріжних каменів утопічного ідеалу Платона і потім зіграє свою роль у формуванні політичних поглядів Арістотеля.

Як стверджує В.Нерсесянц, «у плані теоретичному сократівський ідеал був спробою сформулювати ідеально-розумну державу, а щодо практичної політики він був спрямований на утвердження принципу компетенції у полісному управлінні» $[8,128]$. Розуміючи, що в демократичних Афінах не існує ідеальної касти мудреців, Сократ знижує модальність своїх вимог і висуває тезу про необхідність удосконалення існуючого ладу за рахунок підвищення компетентності правителів.

Ідеї прогресивності розвитку суспільства висловлювали Платон і Фукідид, але вони простежували цей розвиток лише до певної межі (Платон - до епохи, що передувала Солону, Фукідид - до часу Перикла), тобто поки прогресивний розвиток суспільства відповідав інтересам тих груп, до яких вони належали.

Проблемі ідеальної держави присвячені й твори Платона «Держава», «Політик», «Закони». Платон висуває ідею жорсткого поділу громадян на три класи: працівників, воїнів і правителів. Цей поділ Платон обгрунтовує різноманітністю потреб і необхідністю поділу праці. Але, як зауважує В.Асмус, «для Платона надзвичайно характерно, що значення поділу праці у суспільстві він розглядає не $з$ точки зору працівника, що виробляє продукт, а винятково 
3 точки зору споживачів, що належать в грецькому полісі до класу рабовласників» [9].

Простежуючи загальні закономірності розвитку ідеалу, відзначимо, що в «ідеальній державі» Платона з його суворою, навіть дріб'язковою регламентацією «не лише робітники нагадують рабів, а й члени вищих класів не знають повної і справжньої свободи. Суб'єктом свободи і вищої досконалості виявляється у Платона не окрема особистість і навіть не окремий клас, а тільки все суспільство, тільки держава в цілому» $[10,178]$. Проблема співвідношення особистості й суспільства (під яким у даному випадку розуміється грецький поліс) вирішується у Платона на користь суспільства, що $\epsilon$ характерним для ідеалів традиційного суспільства.

Ідеал Платона має, безсумнівно, політичний характер, оскільки в центрі його уваги стоять питання держави, класів, політичної влади, прав, обов'язків тощо.

Двоїстість позиції Платона по відношенню до рабства, ідеалізація ним перехідних суспільних відносин, спрямованість його ідеалу до «золотого віку» визначили широкий вплив його поглядів на подальший розвиток розуміння суспільного ідеалу (проекти Евгемера, Гіпподама; ідеали ієрархічного феодального суспільства; утопічна теорія Т.Кампанелли; ідеал просвітників тощо).

Якщо ідеал Платона - це ідеал рабовласницького суспільства, яке утверджується, то ідеал Арістотеля породжений інтересами міцно утвердженого рабства. Це ідеал зрілих відносин позаекономічного примушення до праці.

Смисл досконалого, ідеального життя Арістотель вбачає у досягненні блаженства, що розуміється як сократівське споглядальне осягнення істини. I хоча ця мета повною мірою досяжна лише для богів, людина також повинна до неї прагнути.

Запозичуючи у Сократа етичний ідеал, Арістотель розробляє проблеми становлення і змісту ідеалу і тим самим робить свій внесок у наукове розуміння його сутності. Арістотель пропонує розглядати ідеал як кінцеву мету, яка не може служити засобом для чого б то не було. Усі інші, кажучи сучасною мовою, елементи соціальної дійсності, прямо або опосередковано служать ії досягненню. Кінцева мета, за Арістотелем, - це і «блаженство», і «дозвілля».

Хоча сам Арістотель ніде про це прямо не пише, але «дозвілля» $\epsilon$, по суті справи, однією із знаменитих арістотелівських вільних від конкретного змісту, загальних, незмінних, вічних форм, у даному 
випадку - формою життєдіяльності рабовласника. Арістотель наповнює цю форму «блаженством», тобто споглядальним знанням, i іншого змісту для неї не мислить. Але пізніше, в інших умовах, вона змогла увібрати в себе і «чуттєвість» Епікура і стоїцизм Сенеки.

Шляхом логічних побудов Арістотель зводить «блаженство» на вершину створеної ним піраміди цілей і засобів і намагається осмислити всю досить складну систему економічних, соціальних і політичних відносин сучасного йому суспільства 3 погляду їх підпорядкованості цьому ідеалу, а також перетворити їх в ієрархію. До сфери економіки належать проблеми власності, багатства і самого рабства, і Арістотель, відповідно до свого розуміння ідеалу, поміщає їх на нижчий рівень соціальної піраміди. Але, маючи ці елементи в основі піраміди цілей і засобів, Арістотель дає їм однозначне класове тлумачення: раб - це одушевлений інструмент, це двигун, який приводить до руху всі інші інструменти.

На противагу Платону Арістотель не мислить ідеальне суспільство без приватної власності. Якщо в реальному, сучасному йому, суспільстві приватна власність сприяє кращій організації господарства, то в досконалій державі іiі значення зростає ще більше, адже кожен буде 3 ретельністю ставитися до того, що йому належить. Відносно багатства Арістотель дотримується «середини», яка близька до демокрітівської «міри». Заклик Арістотеля до поміркованості у багатстві випливає і з його розуміння діалектики цілі і засобів i, можливо, із зумовленості його поглядів соціальним походженням. Накопичення не повинно ставати для рабовласника самоціллю, оскільки у цьому випадку він обмежує, збіднює себе як споживача.

Наступним за економікою рівнем в арістотелівській піраміді $\epsilon$ політика. Як сім'я і селища підпорядковані державі, так і економіка підпорядкована політиці. Політика і держава покликані зберегти той суспільний стан, за якого панівний клас може вести «благе життя», тобто існувати як істинно панівний клас. В основі всіх катаклізмів лежать полярність інтересів, суперечність між багатими й бідними.

Арістотель пропонує поставити на чолі держави «середній клас», який, природно, є рабовласницьким. Про рабів, як таких, що належать до сфери економіки, взагалі не йдеться, вони служать лише п’єдесталом цього суспільства. Ремісники, торговці, землероби, у яких немає «дозвілля» і яким властива «низовина інтересів», незважаючи на свою присутність в ідеальному суспільстві не входять у 
його соціальну структуру. У вирішенні проблеми взаємовідносин між особистістю й суспільством, Арістотель йде за Сократом. Його ідеал - індивідуалістичний, оскільки споглядальне пізнання істини - це доля індивідів. Арістотель заперечує аскетичний, казармений спосіб життя платонівської держави і вважає, що люди повинні керуватися у своїх вчинках егоїзмом, стримуваним мірою.

Арістотель остаточно позбавляється впливу міфологічної форми попереднього суспільного ідеалу і дає своєму ідеалу чисто раціональне обгрунтування. На його думку, ідеальна держава може бути створена шляхом перебудови однієї з реально існуючих сучасних йому держав. I в цьому розумінні арістотелівський ідеал $є$ цілком оптимістичним.

Арістотелівським ідеалом завершується період еллінізму у розвитку уявлень про ідеальне суспільство. Приблизно до кінця IV ст. до н.е. в економічному, соціальному й політичному житті Давньої Греції починаються процеси, які позначилися і на формуванні рис майбутнього суспільного ідеалу, і на змісті ідеалу рабовласників.

У формуванні елліністичного світогляду певну роль відіграла і та обставина, що на практиці ідеали Платона й Арістотеля залишилися нереалізованими. Грецька філософія, яка зросла на полісному грунті, в період остаточного розкладання полісної організації не могла дати позитивної відповіді на питання про належний суспільний устрій, політичні питання у цей період практично зникають $з$ іiі проблематики. «Філософія починає цікавитися не стільки світом, скільки долею у ньому людини, не стільки загадками космосу, скільки спробою знайти спосіб, який у суперечностях і бурях життя дав можливість людині знайти таке потрібне їй і бажане заспокоєння» [10, 424].

Криза і аристократичної, і демократичної форм правління, завоювання Греції Македонською монархією, а потім Римом істотно вплинули на світогляд прогресивних соціальних верств, стали однією з причин деполітизації суспільної свідомості. Населення Давньої Греції та особливо Афін, що протягом декількох століть пожинало плоди успішних загарбницьких війн, тепер саме виявилося об'єктом поневолення і потребувало нових суспільних орієнтирів. Завдання їх опрацювання взяли на себе дві філософські школи, які практично одночасно виникли й паралельно розвивалися - епікуреїзм і стоїцизм.

Епікур вважав, що для людини як чуттєвої істоти вищим благом 
$\epsilon$ «блаженство», що розуміється як задоволення, насамперед, як відсутність страждань, уміння їх уникати. Епікур стверджує це з усією впевненістю: «Коли ми говоримо, що задоволення $є$ кінцевою метою, то ми розуміємо не задоволення розпусників і не задоволення, що полягає в чуттєвій насолоді, як думає дехто, хто не знає, або не погоджується, або неправильно розуміє, але ми розуміємо свободу від тілесних страждань і душевних тривог» [Цит. за: 11, 131].

Цей перший орієнтир для представника демосу, який втратив віру у свої колишні орієнтири, цей етичний принцип є цілком інтровертивним і в цьому розумінні індивідуалістичним. Блаженство індивіда залежить, передусім, від його особистої поведінки. «Усе об'єктивне для особистості стало тепер зовнішнім, і пізнає вона його тепер тільки крізь призму своїх внутрішніх переживань» $[5,118]$.

Таку саму спрямованість має і другий орієнтир, що висувається Епікуром, - «живи непомітно». Детально цей принцип обгрунтовується у римській школі епікуреїзму, у творчості Тіта Лукреція Кара [11].

Якщо врахувати, що вчення Епікура і вчення його римських послідовників виникають у кризові, смутні часи античної історії, то напрошується висновок, що життєві принципи, які пропонувалися Епікуром, якнайкраще відповідали світогляду тих ремісничих і торговельних кіл, для яких головним «задоволенням» була можливість якщо не уникнути страждань, то хоча б суб'єктивно притупити їх гостроту.

Дійсні творці «епікурівського» ідеалу не замислювалися над проблемою перебудови існуючого суспільства, не виробляли уявлень про досконалий стан суспільства, в якому їх ідеал міг би бути реалізований найбільш повно. «Кінцева» мета повсякденно здійснювалася на практиці. Тому реальне рабовласницьке суспільство виявляється ідеальним для досягнення цієї мети. Виникла унікальна ситуація пояснюється тією обставиною, що висунуті суспільною думкою ідеї в результаті свідомої підміни понять виявилися ніби в руслі корінних інтересів панівного класу. Все це дає підстави стверджувати, що форма рабовласницького ідеалу не містить у собі програми зміни суспільства і не $є$ ідеалом суспільного устрою в точному розумінні слова.

На противагу епікурейцям стоїки вважали, що процес деградації суспільства почався вже давно. Ідеальне суспільство, на їхню думку, існувало в «золотий вік». 3 волі невблаганної долі це суспільство поступово деградує, і з цим, вважали стоїки, люди повинні змири- 
тися. Тому, їх етична концепція являє собою ще одну форму світоглядного пристосування демократичних верств елліністичного i, насамперед, римського світу, який розкладається, до існуючих суспільних відносин. Проповідувані стоїками життєві установки логічно виводяться з постулату про єдність світу, природи. Мета всіх живих істот - жити в гармонії з природою. Людина повинна жити у злагоді з Логосом, у якому природа досягає своєї досконалості і який править світом. Вища мета життя - безтурботність, або «атараксія», може бути досягнута тільки в результаті життя згідно 3 чеснотами - життя розумного, узгодженого з природою.

Використовуючи арістотелівське уявлення про кінцеву мету, стоїки проголошують звільнення людини від зовнішніх речей. Джерело кінцевої мети, чесноти, містяться всередині людини, в іiі розумі. Зовнішні речі, навіть якщо вони належать до розряду «належних» (тобто відповідні матеріальним потребам, найпростішій природі), є лише засобами досягнення кінцевої мети. Мудрець, що розуміє їх справжнє значення, ніколи не опиниться в підпорядкуванні у них. Він добровільно приймає все, що відбувається у світі як необхідне, неминуче. «Велич душі - це знання або самовладання, що дає змогу бути вище всього, що з тобою відбувається, як доброго, так і поганого» $[12,297]$. В умовах суспільних суперечностей, що дедалі більше загострювались, стоїки вбачають єдиний вихід у моральному вдосконаленні індивіда, в його зовнішньому підпорядкуванні дійсності і в суб'єктивному звільненні від неї.

Уявлення Ціцерона про належний стан суспільства за своїм масштабом, за ступенем опрацьованості й деталізації стоять в одному ряду з ідеалами суспільного устрою Платона й Арістотеля. Але сам Ціцерон вбачає відмінність своєї концепції найкращої держави від платонівського ідеалу у тому, що вона реально здійсненна і вже існувала у формі сенатської республіки. Найкращою, на думку Ціцерона, є змішана форма державності, оскільки «бажано, щоб у державі було щось видатне й царське, щоб одна частина влади була приділена і вручена авторитету провідних людей, а деякі частки були надані думці й волі народу» $[13,69]$. Такій державі відповідає ідеальний громадянин, мудрість якого полягає не у відстороненості від суспільного життя (як радили епікурейці), а в діяльності на благо суспільства, в наданні допомоги людям, що постраждали від несправедливості, перша вимога якої полягає в тому, щоб ніхто нікому не шкодив, оскільки всі люди - громадяни одного граду. 
Уявлення Ціцерона про належний стан суспільства здійснили великий вплив на формування ідеалів Августина Блаженного i представників епохи Відродження, на суспільну думку епохи Просвітництва. Але в сучасній йому Римській імперії, в міру іiї занепаду, наростала загальна апатія й деморалізація. Сенека, Марк Аврелій та інші створюють останній рабовласницький ідеал, в якому на місце «задоволення» поставлена «чеснота», тобто безтурботне, відчужене від зовнішнього світу і водночас покірне йому життя індивіда. Стоїки, як і епікурейці, не дають розгорнутого уявлення про ідеальне суспільство. Суспільне життя як частина природи управляється непорушним законом і не може бути довільно змінене за бажанням людей. Тому, вироблення планів перебудови суспільства суперечило б самим основам стоїчної філософії. Втім, стоїки не зневажають політичної проблематики - мудрець «повинен брати участь у громадських справах».

Виходячи $з$ принципу єдності природи, стоїки розглядали всіх людей як членів світового цілого. На їхню думку, всі люди рівні від природи, і чеснота не є вродженою якістю. Будь-яка людина може іiі досягти в результаті навчання і практичних вправ. У Римській імперії, що стоїть на порозі свого занепаду, громадські низи вбирали ці ідеї і стихійно виробляли на їх основі той принцип абстрактної рівності, який в ілюзорній формі увійшов в ранньохристиянський суспільний ідеал.

Послідовно проводячи свої ідеї, стоїки проголосили і рівність між вільними і рабами. Але це рівність - рівність перед Логосом, по відношенню до якого всі люди, в кінцевому рахунку, раби. Вільним $€$ тільки розум людини, причетний до Логосу.

Політичним ідеалом земних (малих) держав Сенека, наприклад, вважав імперію, обмежену сенатом. Але справжньою державою для мудреця є держава, яка керується Логосом і об'єднує всі «малі держави». Таким чином, стоїцизм створює модель держави, яка, по суті своїй, є вже досить близькою до «царства божого» раннього християнства

Отже уявлення про необхідність формування поняття ідеалу виникають у суспільстві з появою приватної власності, тобто з розшаруванням суспільства на класи. Питання про ідеальну соціальну організацію завжди було предметом суперечок і дискусій серед найбільш впливових філософів минулого. Вирішення цього питання залежало від тих історичних умов і соціально-моральних позицій, 
в яких перебував той чи інший автор. 3 поглибленням і загостренням державної кризи вектор вирішення питання про суспільний ідеал від пріоритету державності повертався, власне, до людини, тобто до пріоритету особистісних свобод, інтересів і потреб.

\section{ЛIТЕРАТУРА}

1. Гусев Г.М. Странствия Великой Мечты: история развития идей о совершенном общественном строе. - М., 1987. - 430 с.

2. Людвиченко М.В. Утопія і футурологія у контексті формування соціальних ідеалів: автореф. дис. ... канд. філос. наук: 09.00.03. - К., 2010. - 15 с.

3. Ильенков Э.В. Идеальное и идеал // Ильенков Э.В. Философия и культура. - М., 1991. - С.204-274.

4. Туманов С.В. Общественный идеал: диалектика развития. - М., 1986. -198 с.

5. Лосев А.Ф. История античной эстетики. - Т.1: Ранняя классика. - М., 1963. $-583 \mathrm{c}$.

6. Лосев А.Ф. История античной эстетики: Софисты. Сократ. Платон. M., 1994. $-714 \mathrm{c}$.

7. Фролов Э.Д. Огни Диоскуров: античные теории переустройства общества и государства (О Сократе, Ксенофонте, Исократе). - Л., 1984. - 193 с.

8. Нерсесяни В.С. Политические учения Древней Греции. - М., 1979. - 261 с.

9. Асмус В.Ф. Платон. - М., 1969. - 245 с.

10. Асмус В.Ф. Античная философия. - М., 1976. - 543 с.

11. Лукреций К.Т. О природе вещей. - Т. 2: Статьи, комментарии, фрагменты Эпикура и Эмпедокла. - М., 1947. - 699 с.

12.Лаэртский Д. О жизни, учениях и изречениях знаменитых философов / Диоген Лаэртский. - М., 1979. - 618 с.

13. Цицерон M.T. Диалоги: О государстве. О законах [пер. с лат.]. - М., 1966. $-224 \mathrm{c}$.

Дзьобань О.П. Суспільний ідеал: деякі особливості античного розуміння.

В статті аналізуються погляди ідеального державного устрою, яку розв'язували філософи античності. Вперше ця проблема була поставлена софістами, одні з яких вважали, що приписи законів є довільними (штучними), тоді як веління ж природи є необхідними, а інша група софістів робила висновок, що потрібно встановлювати такі закони, які відповідають користі людей, а саме - взаємній справедливості та іншим чеснотам.

В творах Платона проблема співвідношення особистості й суспільства 
вирішується на користь суспільства, що є характерним для ідеалів традиційного суспільства. На противагу Платону Аристотель не мислить ідеальне суспільство без приватної власності.

3 поглибленням і загостренням державної кризи вектор вирішення питання про суспільний ідеал повертався від пріоритету державності до людини, тобто до пріоритету особистісних свобод, інтересів і потреб. У формуванні елліністичного світогляду певну роль відіграла і та обставина, що ідеали Платона й Аристотеля залишилися нереалізованими на практиці.

Показано, що вирішення питання про ідеальну соціальну організацію залежало від тих історичних умов і соціально-моральних позицій, в яких знаходився той чи інший автор.

Ключові слова: античність, суспільство, ідеал, політика, свобода, справедливість.

Дзебань А.П. Общественный идеал: некоторые особенности античного понимания.

В статье анализируются точки зрения представителей античной философской культуры на сущность социального идеала и возможность его практического достижения. Обосновывается мысль о то, что представления о необходимости формирования понятия идеала появляются в обществе с возникновением частной собственности, то есть с расслоением общества на классы. Показывается, что решение вопроса об идеальной социальной организации зависело от тех исторических условий и социально-нравственных позиций, в которых находился тот или иной автор.

Ключевые слова: античность, общество, идеал, политика, свобода, справедливость.

Dzioban O.P. Social ideal: some Peculiar Features of its Understanding in the Ancient World.

In the article there is analyzed the ideal state system problem, the latter having been the core problematic point for the ancient philosophers. For the first time, the problem had been set by sophists. Some of them considered legal provisions to be artificial vs. necessary orders of nature. The other group came to a conclusion that it is necessary to lay down the laws to correlate with the utilitarian human needs including those based on justice and others virtues.

In Plato's works the problem of correspondence between a person and the society is balanced in favor of the society, and it is typical for the ideals of a traditional society. Contrary to Plato's view, Aristotle's concept of an ideal society is considered impossible without private property.

The vector of state crisis having become acute and in-depth, the question on social ideal reverted to the human priority in the correlation of a person and 
the state, thus implementing priority of personal freedoms, interests and needs. Hellenistic worldview was formed under the relevant influence of the fact that both Plato's ideas and Aristotle's ones had remained without any practical achievements.

There is also stated that the question on an ideal social organization depended on the historical context and social-ethical provisions having been postulated by the authors under analysis.

Key words: antiquity, society, ideal, politics, freedom, justice. 